\title{
Social Themes in Saudi Women Short Stories: Making the voice of Women Heard
}

\author{
Abdulrahman Mokbel Mahyoub Hezam \\ Department of English, Faculty of Arts \\ Taiz University, Yemen \\ $\&$ \\ Department of Languages and Translation \\ Faculty of Science and Arts \\ Taibah University, Al-Ola, Saudi Arabia
}

\begin{abstract}
Few studies in English have been carried out to explore the realm of Saudi short stories in general and women writers' works in particular. The aim of this paper is to examine how Saudi women short story writers used a western literary form to depict the realities of their country. It also delineates the magnificent representation of social themes through storytelling and provides nonArabic speakers with an insight into the writings of Saudi female writers. It tries to present a vivid picture of how these stories reflect the social reality in Saudi Arabia in the last few decades of the 20 th century and the challenges facing women in this transitional period. Moreover, the study tries to examine how women writers participated in the contentious debates regarding women that dominated the Saudi society especially on questions like marriage, divorce and women education. The present study is basically a text-based research that involves an analysis of major primary sources chosen. Selected short stories written by Saudi women writers are examined from a thematic perspective to reveal the ways in which women writers incited social change by defining notions of gender and social space and how they give voice to the Saudi women.
\end{abstract}

Keywords: Gender, Saudi women writers, social themes, short story

Cites as: Hezam, A. M. M. (2018). Social Themes in Saudi Women Short Stories: Making the voice of Women Heard Arab World English Journal for Translation \& Literary Studies, 2 (4). 152-163.

DOI: http://dx.doi.org/10.24093/awejtls/vol2no4.11 


\section{Introduction}

Literature and reality are the two sides of the same coin. Literature is the mirror through which we can see reality and follow the transformations within society. Representations of women in literature serve as a barometer by which we can measure the position and role of women in any society and trace the development of their status especially in transitional periods. In addition to its role in helping us understand the social conditions, literature has also played a major role in bringing about change and reshaping the mindset of society. It refashions the culture and document the refashioning. This relationship between literature and change is even more important in societies that are deemed conservative. Al-Sudeary, (2012) tells us:

In an age where sensitivities and prejudices are growing against Muslims, literature becomes an important venue to correct or reinforce existing stereotypes about the Muslim woman. At a time where the political and literary are the one and the same, it is a certainty that what is to be found in the literary domain reflects the political arena as well as the fact that the literary is an agent which aids and abets the political scenario. (p. 69)

The fast economic development in the 1970s, brought attention to women's issues in Saudi Arabia in a way that could not be ignored, especially with dramatic social change that resulted from the economic upsurge. Revenue gained from oil production in the early 1970s introduced major economic, political and social changes; The whole structure of society was affected including the status of women. Questions were raised regarding the place of women in society, their right for education, work and equality. The rise of education was an important outcome of the socioeconomic change and a factor in the rise of women writing. Women got the chance to study and some of them even sought education abroad which resulted into more awareness on the part of women regarding their status and the need for changing it. Based on Hamdawi's Bibliography of Very Short Story in Saudi Arabia published in 2015, one can argue that, though, short story emerged as a significant form of literature in Saudi Arabia in the 1970s, it emerged as a dominant women mode of writing only in the 1990s. Stories written by Saudi women at the early stages bear witness to the rapidly transforming social, historical and economic conditions of Saudi Arabia. Therefore, they can be considered important documentation of this evolutionary period in the history of the kingdom.

\section{Methodology}

The present study is primarily a text-based research that involves a thorough analysis of major primary sources chosen. Selected short stories written by Saudi women writers are examined from a thematic perspective to reveal the ways in which women writers incited social change by defining notions of gender and social space and how they give voice to the Saudi women.

Significance of the study

Despite the significance of the short story as a literary form, it has not received as much critical attention in Saudi Arabia as other forms of literature such as poetry and novel. Few studies in English have been carried out to explore the realm of Saudi short stories in general and women writers' works in particular. One of the objectives of the study is to show how Saudi women short 
story writers used a western literary form to portray social life and present social themes through storytelling. The study provides non-Arabic speakers with an insight into the writings of female writers in Saudi Arabia. It tries to present a vivid picture of how these stories reflect the social reality in Saudi Arabia in the last few decades of the 20th century and the challenges facing women in this transitional period. It also tries to examine the form from the viewpoint of thematic concerns and characterization and show how these stories have similarities and variations in themes, characters and styles despite the fact that they are writing about the same time and circumstances..

\section{Why the short story?}

There were reasons why women writers chose to write short stories; not just by compulsion of any sort but necessarily by choice. Saudi women writers realized the potential of this short genre and began using it as a powerful tool to criticize patriarchy in Saudi society that proved detrimental to the position of women. The range, complexity and variety of the Saudi short story grew continuously to make it the most powerful narrative medium. The thematic component was varied where one can find the rural and the urban, the traditional and the modern, and the gender question. Various themes occupied the attention of the short story writers at various stages in the history of the new form. According to Alsudairy (2017), most women writers in Saud Arabia started their literary production with the shorts story." The choice provides the mask for women authors to hide behind, and express freely their opinions or what they long for"(56) The Short story was a preferred form for women writers because it helped them in consolidating their ideas and present them in a compact form. They found in the short story a literary form that despite its shortness is deep, intense and complex. They also found in the new form what Mary Rohrberger calls" the encompassing of time and motion in a present moment, while simultaneously suggesting past and future"(10). Poe, (1994) tells us that a story should "not exceed in length what might be perused in an hour" (Poe 1994, p. 60). In this way the focus is intense and the understanding of the theme is deep. The shortness of the form enables the writer to "to carry out the fullness of his intention, be it what it may. During the hour of perusal the soul of the reader is at the writer's control" (Poe 1994 p. 61). H. G. Wells (1912) defines: "A short story is, or should be, a simple thing; it aims at producing one single vivid effect; it has to seize the attention at the outset, and never relaxing, gather it together more and more until the climax is reached. The limit of the human capacity to attend closely therefore set a limit to it: it must explode and finish before interruption occurs of fatigue sets in" (P.19) short stories, therefore are precise in delivering their messages and conveying the writer's intentions.

The short story, as a form of art, is used by Saudi women writers to represent the social values and visions of their society and culture. The last decades of the 20th century witnessed rapid development in all aspects of life in Saudi Arabia. This development resulted in many social and economic transformations. The appearance and rise of the short story in the kingdom is closely associated with the social and cultural evolution in all aspects of life in Saudi Arabia. It was the most appropriate medium for expressing the increasing national and individual awareness and manifestation the fast developing Saudi society. In a relatively brief period the country witnessed urbanization accompanied with mass education, occupational specialization and a shift from tradition to modernity. This change gave rise to the conflict between modernity and tradition, and

Arab World English Journal for Translation \& Literary Studies 
between the new and the old. These writings comprises of middle-class definitions of family, marital relations and the rights of women. They decided to throw the veil that has covered their mental abilities and prevented them from expressing themselves. They decided to go out to the world with firmness of purpose and a new confidence. They had to face a lot of obstacles created not only by men but also other women as well. Their works exemplify these actions and reactions. They opined that women were fettered by stereotyped roles that society had conferred upon them and they wanted to change that by following their own course and ideas.

There are some social, political and economic factors that have contributed to the flourishing of short story in Saudi Arabia in the 1990 including: political stability, economic augmentation and the social changes that Saudi society underwent during the period. Rise of literacy is another factor that aided the spread of short story when many Saudi young men who studied abroad in the preceding decades returned home with the zeal and zest to bring real literary change in the country. In addition to these factors journalism played important role in popularizing the new literary form. Many stories were published in newspapers and literary magazines. By publishing their works in the rapidly expanding periodical press, Saudi women writers inspired social change by altering the perspective that people towards the world - and the women - around them According to Hamdawi(2015), short story in Saudi Arabia appeared in the mid-1970s as first attempts were published in newspapers, journals and other literary outlets. Literary and cultural forums, associations and institutions also contributed to the spread, flourishing and criticism of the new literary form. (P.9) these stories used the classic narrative techniques and the new expressive modern techniques to deal with various issues ranging from the personal to the public issues, from the individual to the social.

The emergence of the short story in Saudi Arabia in the second half of the last century and the beginning of the current century coincided with the rise of the professional woman writer. Short stories published by women writers contributed to ongoing debates regarding the place of woman in society and their rights. The conflict created by the shift from tradition to modernity and from the old to the new become the content for Saudi women writers. They tried to discover innovative patterns of asserting female self-hood, forming a new feminist consciousness in keeping with changed times in the country and showing increasing courage in breaking old practices regarding woman's place in society.

Some of the prominent Saudi women writers who have inspired, redefined the lives of women and created new life patterns are Fawziyya Al-bakr, Badriyya Al-Bisher, Maryam alGhamidi, Noura al-Ghamidim Umaima al-Khamees, Khairiyya Ibrahim al-Saqqaf, and Shareefa al-Shamlan. The writers use short story as a tool for social critique, a means of calling for social change and justice, and a tool for social transformation. They escaped the bonds of the enclosed home, entered the public sphere and tried to reshape it. Through their short stories one can learn how gender roles developed in a growing middle-class society within premises of home, the city, and the village. The social and cultural change in Saudi Arabia in the late 20th century has made women conscious of the need to redefine themselves and their position in society. The main objective was to express woman's struggle in the context of contemporary Saudi society, and to 
determine her place and preserve her identity as wife, daughter mother and as a human being. Man-woman relationship in a changing society is also one of the main themes that Saudi women writers grapple with. The heroines of some of these stories try to surmount the limitations of their prescribed roles by redefining their boundaries and struggle hard in a male-dominated world to discover their own identity. These writers' innovative works ask readers to reconsider where women could live, how they could be identified, and whether they could be controlled. The stories presents different perceptions of reality that are intended as an opposition to established knowledge. Using different techniques ranging from the traditional narrative modes to the use of symbolism and combining the realistic and the fantastic, they were able to deal with women's problems in a fast-changing society that was moving forwards towards modernization

\section{Marriage and Divorce}

Saudi short stories deal with a wide range of themes. They reflect Saudi culture, tradition, social values and even Saudi history through the depiction of life in Saudi cities, towns and villages. Many of the short stories reveal the centrality of family and social relationships. The concepts of marriage and family are recurrent themes. They are often used as devices to convey social fears and aspirations, and provide insight into the inner-most workings of man-woman relationship at its most intimate. Marriage institution remains the most important challenge for woman. It is in this closed-in arena that every married woman is to fight out her battle as an individual. In a conservative society, when we talk of marriage we usually mean arranged marriage in which women usually have very little say in their matrimonial destiny. Writers examine this institution from all aspects and show the psychological, social and emotional consequences of this type of marriage. One of these consequences is divorce which is a natural outcome of bringing together two different minds. Um Suleiman in Badria al-bishr's The School's Caretaker (Hāzimī,2006) is part of the traditional arranged marriage. She stands for the past that was in conflict with the present. Al-bishr is one of the writers who have taken to the short story form seriously with clear intentions. In this story, she presents a good example of the conflict between tradition and modernity,and the old and the new. The writer tells us that Um Suleiman "was the one behind many of the girls' marriages, and many of those still left had pinned their hopes on her to find their new prince, in her worn-out notebook" working as a school caretaker, Um Suleiman had had the privileged role of finding a husband for the school headmistress. She convinced her through telling her how short life was, and how "unmarried women soon ceased to be eligible.

Najat Khayyat also voices the suffering of some women in arranged marriages. The title of the story One Day the Sun Will Rise(Hāzimī,2006) is symbolic because it shows marriage as darkness and freedom from it as the rising of the sun, the protagonist of the story gives a very extreme definition of the husband "The husband - the worms living with you now, silting up your lake - this husband provides your bread and butter, but he takes a double price in return, from your mind and your life." She goes to say "Oh patience, help me. Isn't it time, you sun, to rise on my black horizon, and take pity on me and my pain? The stench of my silted lake repels me."(p. 207) she also calls her husband " the tyrant slave master" who owns every part of her. Her married life for her is only a " dark grave" where she has remained in darkness for a long time. It is time for her to rebel and regain her freedom. When she succeeded in obtaining her freedom, she was born 
again. " Always after that, whenever I was asked my date of birth, I'd give my answer without the smallest hesitation. I was born, I'd say, the day the sun rose."(p. 210) in Their Lifeless Bodies (Hāzimī,2006) the daughter is different from her mother. She refused to live with someone she does not love. The writer tells us that" she wasn't like your mother who did not mind that there was no love between her and your father, who was content to be his wife and live at his feet" (p. 400)

Another story that deals with arranged marriage is "Is There an End"(Hāzimī,2006) by Qumasha Al-Alyan , her lifelong dreams of marrying the man of her dreams, she has night-marelike wedding in which she sees her white clothes as her coffin ' my husband next to me will be the next grave .. And those who celebrate my wedding are the mourners at my funeral .. The wedding hall and the bouquets of the daffodils are the same as the marquee of consolation and the voice of the Koran reader.." she was divorced after a few months of her marriage without " touching my impossible dreams..... I remained suspended between the earth and the sky, the earth did not hold me contradictions and rebel, nor sky swallowed me to rest". The identity of woman is one of the most important themes in Saudi short stories written by women. Some stories preset married women as having lost their identity and become part of the household. Talking about Layla alUhaydab's story, "Nisa'" (Women), Su'ad al-Mana (tells us that this story "portrays the daily hardship undergone by women in a style that blends the fantastic and the realistic." She argues that the story shows that common household and marital duties have turned women into carbon copies," indistinguishable from one another; even they barely notice the difference between one home and another, in which each woman plays out her preordained role."(p.268)

Some of the stories give a detailed description of the routine life of a married woman. In her story And the Step Changed (1982) Khairiyya Ibrahim al-Saqqaf describes the life of a wife "She was used to being the first to wake. She'd pray, then put the coffee on a fire with which she'd kindle the first log of endless love. ........... She'd prepare a slice of bread and cheese, then take it to him along with the coffee. Then, after that, he'd start a long day filled with toil and struggle"(p.237) although her marriage was an arranged one, she still loves her husband. she is so fond of him to the extent that " Sometimes he'd laugh, the way everyone did. Just an ordinary thing, but for her a day when he laughed was a day of deep happiness, because he was the whole world to her, and everything else was commonplace, not worth her attention( p.238) As a reward for her love and devotedness, her husband left her when he got an educational degree. He left her because she is no longer suitable for him as she cannot read or write. She was forced to marry another man "On her wedding night, the wet earth was mingled with the tears coursing down her cheeks. 'Awwad had possession of her hand, but not of her heart. As she turned her back on her father's house, she was trampling the last part of that heart that was still alive.(p.239) The story presents the suffering of the protagonist as she cannot understand what is happening to her or why?

In many of the stories, women have been denied their voices by men, their ideas often discarded and men have made decisions without allowing them to be part of the process. They have been marginalized and this results in a sense of frustration and boredom. In her story, My Hair Grew Long Again! (Hāzimī,2006), Hussa Muhammad al-Tuwaijiri presents a bored wife,

Arab World English Journal for Translation \& Literary Studies 
gives us her feelings and the conclusion she reached that life with her husband was growing tedious and stagnant. There was nothing new about her life with the man she does not love. They are constantly disagreeing over so many things.""The odd thing was that we were different from other married couples. We never discussed our problems aloud, nor did we argue. We just took to silence, and the silence between us was growing by the day." (p.247) she tells us that there is nothing worse than living without affection. Unlike Della in O. Henry's The Gift of the Magi, who cut her hair to buy a gift for her husband, the protagonist in this story cuts her hair because her husband loves it. Cutting her hair is a sign of her protest and of her desire to assert herself. When he rebukes her for doing so, she gave this eloquent speech"'I'll do whatever I like. I'm tired of your control over me. You treat me as if I was a doll, just there for your convenience. But you were the stupid one. You never thought I might have a will and feelings. I've come to hate myself, because all I do is follow your orders, without having any views of my own. From today everything's going to change. I've cut my hair, and it was my right to do it. And another thing, I'm starting work and I'm going on with my studies. I'll have my own say in this house, even if it's just for a couple of days. I want to feel that I can use my rights."'(p.248) she decided to break the chains of her simple life as " Life was too short to be spent in misery. She refuses to keep suffering in a life that is short. She decides to make her own happiness because as she puts it "happiness isn't a pill we swallow to rid ourselves of the bitterness of despair, but something we work for and earn." (p. 248) He tried hard to get her to return to" an abject life", but she refused and did what she had always wanted to do. She went on with her studies and started working." My hair grew long again and this time I never thought of cutting it!"(p.249) This story is an example of how Saudi women short story writers are concerned with depicting the suffering of women, and what causes unhappiness and pain for women and how women can achieve happiness and ensure their full development and participation in society.

Qumasha al-'Ulayyan , in Days with No Hope(Hāzimī,2006), deals with a unique social problem facing some Saudi women. Unlike the protagonist in My Hair Grew Long Again!, Fatima, the protagonist in Qumasha al-Ulayyan's story loves her husband. Both are the victims of social prejudices where couples are separated from each other by a court's verdict. The story opens in a court room where the judge announced in" a tone of careless indifference " that she must be separated from her husband" on the grounds of general good." My husband was sterile; there was no hope of his having children. Her father tried to calm her down but she questions his false kindness" "Does my future start by separating from my husband? My love, my soul mate, my very life? Has divorce been the beginning? Or has it been a painful ending, then a dark future and an everlasting grief? Was it just, father, that the love of five years should end like this, with such tyranny?"(p.249) like the protagonist in And the Steps Changed , Fatima was forced to marry another man. Her reaction was similar despite the differences in the reasons for divorce from the first husband. She lived out a fearful nightmare. "I felt as if I was being sent to my grave, not to a new life with a new husband. On the night of my wedding, it came home to me how things stood: a new husband, different from my husband and my love. How could I look him in the face, when the other man's image was still right there inside me? How could I love him, when my heart was filled with my first love? How could I be faithful to him, when the other man's love flowed through

Arab World English Journal for Translation \& Literary Studies 
my veins? (p.250) The irony at the end of the story is that the second husband as she discover later, was sterile too.

In her story " Half a Woman"(Hāzimī,2006) Fauzia Alharbi deals with an extreme way of protesting arranged marriage. The young wife tries to commit suicide. She is saved and the story takes place in the hospital. The writer presents the inner thoughts of the heroine as she lies on the bed surrounded with her family. The story also reflects upon society's reaction that how woman's suicide becomes stronger and more deterrent than legitimate rule that prohibits killing oneself. Her brother is more concerned about what the people will say about her than the life of his sister. She breathes her last because as she whispers to her sister" I cannot live half a Woman" This short story reveals to us the wrong social practices in dealing with the other part (female) and the inferior view of women.

\section{Education}

Education is the main factor in the development of any country. Education plays a critical role in Women's Economic and social empowerment. Many Saudi women especially in the rural areas were denied this right. Education helps a woman to be more self-confident in taking decision and planning a better future for herself and her family. It also helps her to become aware of people and places outside her community, broadens her thinking and perceptions and exposes her to a world which might be different from hers. It is the Hend Al-sudairy(2017) states that "Education is the medium to reach the desired knowledge for political, economic and social change. Moreover, it will create new paths among individuals and enable them to be adaptable to newly assigned roles in their society.(p.58) With a change in the education of women has come a change in her personal and social status and her way of thinking and feeling. women have become strivers and aspirers, towards freedom, towards goodness, and equality. Fawziyya al-Bakr in her story A Paper Life(Hāzimī,2006) gives us the joy of a rural girl resulting from the establishment of a new school in her village and her ability to study." After that it became familiar to run to the school house in the early afternoon. Here was the world come to us at last. Here was a new enchantment, seeping into our blood. We weren't just weary bodies any more, and fingers torn by reaping"(p.179)

Saudi women writers realized that Empowerment of women through education can change the existing conditions of women. It involves the building up of a society wherein women can live without the fear of oppression, exploitation and discrimination in a traditionally male-dominated society. In their short stories, one finds two types of women: those who reject traditional gender roles, and those who hold traditional views on gender. In her story The School Caretaker (Hāzimī,2006) , Al-Bishr gives two examples of the school's girls, Hussa who chooses arranged marriage through Um Suleiman and Munira who stands for the new woman who is not willing to sacrifice her education for a husband through arranged marriage. For Um Suleiman too much studying takes away the girl's youth. Education was a mere scrap of paper, not to be compared with the joy of having children, and a husband.

The use of the first person point of view

Arab World English Journal for Translation \& Literary Studies 
Narrative perspective is generally considered a fundamental element in narrative comprehension. With this tool, story writers can guide the point of view from which readers see events and generate a mental model of the story. It is often assumed that narrating a story from the protagonist's perspective increases the readers' inclination to take over this perspective The "I" telling the story allows a character to serve as an involved and active element of the plot. Everything the reader sees, hears and feels is being funneled through that one character. Most of the short stories written by Saudi women are written in the first person point of view. This is very important because it gives more immediacy and connection with the protagonist of the story. There is a direct link between protagonist and the readers who are given the chance of being "inside" the protagonist's head. Emotions are conveyed to the reader without being filtered by th distance of a third person narrator. The information provided in the story is limited to the narrator's direct experience (what she sees, hears, thinks, does, feels, etc.). Thus, an inherent believability is created and this helps in making the voice of the narrators and writers heard.

Najat Khayyat 's story begins "One day the sun will shine on this stagnant lake of mine, wipe away all the sadness and cleanse the silt in the depths." (p.207) Immediately the reader captures the sadness of the narrator resulting from stagnation in her life. We strongly feel the strong emotions of the speaker and this is the first step towards understanding her and sympathizing with her. Here we get the closest possible connection to the thoughts and feelings of the protagonist. One can imagine the closeness the reader feels to the narrator and her emotional state in the first paragraph of Days with No Hope "In a daze akin to submission, I heard the judge's verdict. His strong voice resounded through the hall, piercing with poisoned barbs to my very heart."(p.249) The narrator is speaking directly to the reader, sharing something private that even those who are with her in the court room cannot fully realize. The protagonist in A Paper Life by Fawziyya alBakr introduces herself "I'm the woman from the lands of scorching heat, and of sharp freezing cold that twists the bones"(p.177). The effect of this first sentence is intensified by using the "I" mode. the character's voice comes through clearly, so there is little room for the reader to misinterpret the character's motivations and reactions. We feel a deeper emotional connection to the narrator because we get to know all the thoughts and feelings of the protagonist. Whether the protagonists in these stories are objective in their narration or not cannot be known. What is known to readers, though, is that the narrators are women who suffer because of living in a patriarchal society. They want their voices to be heard, their message to be conveyed, and their situation to be understood. They rightly use the first person point of view in their stories to produce more immediate emotional appeal for readers and closely examine the internal conflict that most of the protagonists undergo.

\section{Conclusion:}

Short story in the kingdom matured considerably in the last decades of the twentieth century. Women's contribution to this new form cannot be disregarded. By addressing a critically neglected form, this study reveals the ways in which Saudi women writers incited social change by defining notions of gender and social roles. For most of the twentieth century, women were seldom given the opportunity to use language in any way to have any power in society. The situation for women began to change gradually in the second half of the century. The last decades of the century

Arab World English Journal for Translation \& Literary Studies 
brought about socio-political changes that gave women more freedom and greater prerogative. They started using the power of language to make themselves heard. The outcome was an emergence of feminine voices from the midst of a male dominated society. Being highly educated and intellectual, they were very vocal and expressive with regard to their thoughts predominantly those regarding women issues.

The new fictional form was able to reflect the socio-cultural realities in the country. The women writers courageously write about difficult and restricted subjects, addressing them with a high standard of professionalism. What adds to the significance of these short stories is that they were Witten by women to tell about being a woman and describe reality from a woman's perspective. The female characters in these short stories are aware of patriarchy and other forces that seek to hinder their development and desire for more emancipation. Many of the characters grow to be very assertive and utilize whatever is available to them to affirm their independence from traditions. They try to live lives worthy of note, even in the face of such barriers as traditions, culture, polygamy and little education. These short stories are meant to show that Saudi society is changing and the situation of women is also changing. Stories present three types of women in this transitional period: the first group hold on to their Muslim religion as a guide to life. Because of the new circumstances, they are forced to reevaluate their commitment to old traditions and reconsider the place given to them. The second group are careless about both cultural traditions and religious practices. The third group include women who are traditional and happy within their domestic responsibilities and try to propagate the traditional set up of her society.

Analyzing these stories will make it apparent how Saudi Arabia has witnessed unprecedented rapid changes during the last decades, when Saudi women writers have been actively expressing their thoughts. The society depicted in these stories compared to Saudi society nowadays seems a remote past. Saudi Arabia has moved from traditional ways of living to a new high-tech world. Recent years have seen major development in the Kingdom of Saudi Arabia and improvement in the opportunities for women in both employment and education, the upliftment of women and bringing them in the mainstream is burning social issue that has become essential for Arab society to progress. The idea is to establish women's identity and dignity in the society. These writers had raised their voices against patriarchal setup where women's individuality has been ruthlessly destroyed.

\section{Suggestions for Further Research}

Very few studies have been carried out on the Saudi short stories in English translation. This critically neglected form needs more attention on the part of researchers to show the non-Arabic speaking societies the creative abilities of Saudi writer of short stories. More studies can be done on other social themes in women short stories and the technical and aesthetic elements of these stories. Contemporary Saudi women have tackled the clash between modernity and tradition, the rise of extremism, environmental hazards, consumerism, and unemployment. All these and other social issues need further studies. 
AWEJ for Translation \& Literary Studies Volume, 2 Number 4. October 2018

Social Themes in Saudi Women Short Stories

Hezam

\section{About the Author:}

Dr. Abdurrahman Mokbel Mahyoub Hezam is an associate professor of English literature and comparative studies at the department of English, Faculty of Arts, Taiz University. Currently he is working as Head of the department of Languages and Translation, Faculty of Science and Arts, Taibah University- Al-Ola, Saudi Arabia ID OrCid: https://orcid.org/0000-0001-9624-906X

\section{References}

Allen, R. (2006). Arab Women Writers: An Anthology of Short Stories World Literature Today: a literary quarterly of the University of Oklahoma (80:4) Jul/Aug 63-64.World Literature Today: a literary quarterly of the University of Oklahoma (80:4) Jul/Aug 63-64.

Al-Rasheed, M. (2011). Economies of desire, fictive sexual uprisings; saudi chick lit: The girls are doing it. Le Monde Diplomatique

Al-Sebail, A. \& Calderbank, A. (2012).New Voices of Arabia - the Short Stories: An Anthology from Saudi Arabia. I. B. Tauris

Al-Sudeary, M. A. (2012). "Rethinking Muslim Woman's Agency in Modern Literature." International Journal of Humanities and Social Science 2 (21)69- 81.

Al-Sudairy, H.T. (2017). Modern Woman in the Kingdom of Saudi Arabia: Rights, Challenges and Achievements, Cambridge Scholars Publishing,

Ashour, Radwa, F. J. Ghazoul \& Reda-Mekdassi, H. (eds) (2011)Arab Women Writers: A Critical Reference Guide 1873-1999, by, and Mandy McClure (trans.)Arab Women Writers: A Critical Reference Guide 1873-1999, by, and Mandy McClure (trans.) Middle Eastern Literatures 14, ( 2).

Bagader, A. \& Deborah, S. Akers, \& Deborahm S. A. (1997).Voices of Change: Short Stories by Saudi Arabian Women Writers. Lynne Rienner Publishers Inc

Crawford, R. (1999). The work of writing: Literature and social change in Britain, 1700-1830. The Huntington Library Quarterly, 62(1), 193-197,201. Retrieved from http://search.proquest.com/docview/215267108?accountid=34864

Harrington, E.B. (2008). "Introduction: Women Writers and the Outlaw Form of the Short Story" Scribbling Women \& the Short Story Form (New York: Peter Lang, p 6-7

Gameel , H.(2015). Bibliography of Very Short Story in Saudi Arabia, Alawlakah, Hammond, J. (1992). H.G. Wells and the Short Story, Palgrave Macmillan UK

Hartman, Michelle: Gender, Genre, and the (Missing) Arab Women Writers and the Politics of Translation Feminist Studies (38:1) Spring, 17-49,267.Feminist Studies (38:1) Spring, 17-49,267.

Ḥāzimī, Manșūr Ibrāhīm \& Khațạāb, 'Izzat ibn 'Abd al-Majīd, 1935- \& Jayyusi, Salma Khadra \& ebrary, Inc (2006). Beyond the dunes : an anthology of modern Saudi literature. I.B.

Tauris ; New York : Distributed in the US by Palgrave Macmillan, London ; New York

Millar, E. (2007). Girls of Riyadh. New Internationalist, , 30. Retrieved from https://search.proquest.com/docview/200056028? accountid=34864

Patrick F. (1998). Review of Ronald Inglehart 'Modernization and Postmodernization: Cultural, Economic, and Political Change in 43 Societies' Canadian Journal of Political Science, 31, pp 391-392. doi:10.1017/S0008423900019934.

Arab World English Journal for Translation \& Literary Studies 
Poe, E.A. (1994). Poe on Short Fiction. In May, C. (Ed.), The New Short Story Theories (pp.5972). Athens: Ohio University Press.

Rohrberger, M. (2004). " Origins, Develoment, Substance and Design of the short story:edited by Per Winther, Jakob Lothe, and Hans H. Skei. (2004). The art of brevity : excursions in short fiction theory and analysis. Columbia :University of South Carolina Press,

Well, H. G.," The Contemporary Novel"(1912), An Englishman Looks at the World (London, 1914) 